\title{
Dormancy of Fig Cultivated under Moroccan Conditions
}

\author{
Ahmed Oukabli*, Abderrahmane Mekaoui \\ Plant Breeding and Genetic Resources, Regional Agricultural Research Centre of Meknes, Meknes, Morocco. \\ Email: *oukabli2001@yahoo.fr
}

Received November $1^{\text {st }}, 2011$; revised December $6^{\text {th }}, 2011$; accepted December $27^{\text {th }}, 2011$

\begin{abstract}
Fig (Ficus carica L.) is a deciduous species well adapted to Mediterranean conditions but its chilling requirement is still not well understood. The present study examines the pattern of bud-break in seven fig cultivars over two years under Moroccan conditions. Evaluation of dormancy behavior was made using a biological test known as "single node cuttings" carried out under controlled conditions. The responses of cultivars from Morocco, Italy, Spain and France were assessed. The period from full leaf fall to bud-break was characterized by a small variation (10 - 20 days) which did not appear to reflect the origin of the cultivars. Steady-sates were at high level in the middle of December or in January depending on the year. During the cold period, MTB didn't exceed 200 days for "Borjassate noire”, "Ournakssi” and "Kadota" and varied from 100 to 128 days for the other cultivars. Therefore, dormancy was not deep and its period was short. Forcing bud during the coldest period allowed to a bud break but it didn't exceed $10 \%$ and dormancy wasn't complete. Missing bud break wasn't observed and the geographic origin of examined cultivars didn't seem to determine the length, and the deepness of bud dormancy. Bud-break occurred within a month of last leaf fall in the cultivars, indicating that they were all suited to commercial production in Morocco. Apparently, bud-break is more reliable in fig than it is in other Rosaceous species in this environment.
\end{abstract}

Keywords: Fig; Dormancy; Bud Break; Varieties; Behaviour

\section{Introduction}

The dormancy of bud has been well studied for rosaceous fruit such as almond, apple, cherry and peach in different environments [1-8]. These authors studied flowers in node cuttings or examined young bud histologically over time for the signs of flower differentiation. The first method allows researches to evaluate dormancy over time, whereas the second method gives researcher an indication on the progress of differentiation and the degree of floral abnormalities, especially under low-chill conditions [9]. Each cultivar has a specific chilling requirement for normal bud break, and it can be estimated by a variety of chill models [1,10-13].

The cultivated fig (Ficus carica L.) is a deciduous species native to arid regions of Asia and is well adapted to the Mediterranean regions [14,15]. It grows well under high light and low humidity [15-18]. Cultivars used for fresh fruit are cultivated under different environmental conditions from those used for drying [19]. Weather has an important effect on productivity and quality. It is cultivated beyond the natural habit in Argentina, Brazil, Mexico and Chile [20]. Spraying of growth regulators

${ }^{*}$ Corresponding author. such as hydrogen cyanamid, pruning treatments and irrigation influence growth and yield. Pruning has been shown to stimulate growth ant not to influence dormancy [21]. Some authors reported that fig is growing better under mild winters [15-18,20], but no data on chilling was given.

In Morocco, the figs account for a substantial part of the area with about 56,000 ha and $60,000 \mathrm{t}$ of production for fresh and dried fruit [22]. It's still grown under traditional agronomics in mountain areas with little value adding. Most cultivars are old local selections which have been maintained by vegetative propagation and confined to different villages $[7,23]$. The horticultural industry aims to expand fig production with a focus on modern orchards yielding 5 to $10 \mathrm{t} / \mathrm{ha}$. The National Institute of Agronomic Research (INRA) has provided new materials adapted to these areas. The chilling requirements of specific cultivars often relate well to the climate where they were selected. The aim of this work was to test if real dormancy exists in fig and to verify if the difference in dormancy intensity exists between different cultivars and if could be related to their geographic origin. Evaluation of dormancy behaviour was made using the biological test (single node cuttings). Dormancy was examined by the pattern of bud-break over two years. 


\section{Material and Methods}

\subsection{Plant Material}

We used seven fig cultivars which have different geographic origins (Morocco, Spain, Frence and Italy) planted in 1995 with 3 trees par cultivar (Table 1), at Aïn Taoujdate, (Meknes region; elev. $500 \mathrm{~m}$; lat. 33:6 N; long. 5:1 W). This site is semi-arid, with an average annual rainfall of about $400 \mathrm{~mm}$, falling mainly from November to March. The soil was calcareous with $30 \%$ of clay. Trees were planted at spacing of $5 \times 3 \mathrm{~m}$ and trained to open vases. The orchard was irrigated from May to September with about $1500-2000 \mathrm{~m}^{3} /$ ha per year. Trees were subjected to normal horticultural practices (pruning, spraying, fertilized).

Chilling hours $(\mathrm{CH})$ were estimated over two years of experiment (2005/2006) using a linear model (CH: (7-m/ $\mathrm{M}-\mathrm{m}) \times 24$ [1] where $\mathrm{M}$ is the maximum and $\mathrm{m}$ is the minimum temperature (Table 2).

\subsection{Evaluating Bud Break}

Node cuttings were used to study bud break [24]. Twigs, 30 - $40 \mathrm{~cm}$ long were sampled every 2 weeks from September until February. The shoots were cut into $4-5 \mathrm{~cm}$ segments, each bearing a single node, with a sample of 20 cuttings per cultivar and harvest date. The tips of the cuttings were covered with paraffin to limit water loss. The samples were maintained at $20^{\circ} \mathrm{C}$, with a photope- riod of about $16 \mathrm{~h}$ and a relative humidity of $90 \%$. Bud break was recorded every 2 days. The mean time of bud break (MTB, days) was calculated according to the formula of [25]:

$$
\operatorname{MTB}=\frac{\mathrm{n}}{1 / \mathrm{T}_{1}+1 / \mathrm{T}_{2}+\cdots+1 / \mathrm{T}_{\mathrm{n}}}
$$

Where $\mathrm{n}$ is the total buds per harvest date and per cultivar and $T_{n}$ is the time period prior to bud break (in days). For each time, the calculation takes into account the distribution of the data around the median.

The experimental design was completely randomised with two replicates for each variety and sampling date. MTB data were analysed 3-way ANOVA using SAS (version 9.00). Studied factors were the "cultivar", "year" and "date" of sampling. The cultivar means were compared using Duncan's method.

Variations in MTB amongst cultivars were also analysed in terms of the evolution of growth capacity of the buds $[2,9,26]$. The time taken from leaf fall to bud break provides an estimate of the length of endodormancy [3]. A high MTB suggests prolonged dormancy bud growth inhibition.

\section{Results}

\subsection{Accumulation of Chilling}

The number of hours chilling below $7^{\circ} \mathrm{C}$ varied throughout the year and averaged $579 \mathrm{~h}$ during the experiment

Table 1. Geographic origins and average dates (2005/2006) of phenological stages for fig cultivars evaluated at the INRA Experimental Station in Aïn Taoujdate, Morocco.

\begin{tabular}{|c|c|c|c|c|}
\hline Variety & Geographic origin & Total Leaf fall (TLF) & Bud break (Bb) & Number of days between TLF and Bb \\
\hline "Filalia” & Morocco & $3 / 12$ & $10 / 3$ & 97 \\
\hline "Ournakssi” & Morocco & $5 / 12$ & $10 / 3$ & 95 \\
\hline "Ghouddane" & Morocco & $28 / 11$ & $10 / 3$ & 102 \\
\hline "Kadota” & Italy & $5 / 12$ & $10 / 3$ & 95 \\
\hline "Leirida" & Spain & $25 / 11$ & $10 / 3$ & 105 \\
\hline "Bourjassote noire" & France & $30 / 11$ & $24 / 3$ & 115 \\
\hline "Longue d'Août" & France & $2 / 12$ & $20 / 3$ & 108 \\
\hline Average & & $2 / 12$ & $13 / 3$ & 102 \\
\hline
\end{tabular}

Table 2. The number of hours below $7^{\circ} \mathrm{C}$ accumulated recorded during the two experiments in Aïn Taoujdate, Meknes, Morocco.

\begin{tabular}{|c|c|c|c|c|c|c|c|c|c|}
\hline Year & September & October & November & December & January & February & March & April & Total \\
\hline 2005-2006 & 0 & 2 & 58 & 158 & 236 & 98 & 38 & 3 & 592 \\
\hline 2006-2007 & 0 & 0 & 7 & 159 & 231 & 65 & 74 & 29 & 566 \\
\hline Average & 0 & 1 & 33 & 159 & 234 & 82 & 56 & 16 & 579 \\
\hline
\end{tabular}


period (Table 2). The monthly break-up of this chilling amount show that the cold period is short and the chilling was recorded principally between November and February. The coldest months are December and January with respectively 159 and $134 \mathrm{~h}$ below $7^{\circ} \mathrm{C}$.

\subsection{The Times of Leaf Fall and Bud Burst}

Leaf fall started in early October and continued for more than two months, depending on the cultivar (Table 1). Complete leaf fall occurred from late November (33 h of chill) to early December. Bud break in the field occurred in early March for Moroccan, Italian and Spanish and French cultivars in late March (Table 1). The period from leaf fall and bud break varied from 95 to 115 days with the longest period recorded for "Borjassote noire". Differences observed among cultivars (10 to 20 days) were not consistent and all of them were sensitive to the environmental factors especially the short photo-period and low temperatures.

The times of bud burst occurred at the same time for all cultivars (end of March) except for the French ones which occurred at the last week of the same month. This phenological stage seems not to be linked to the falling leaves dates. The progress of this stage was not heterogeneous and could be related to their low requirements of low temperatures.

\subsection{Progress of Bud Dormancy Release}

The depth of dormancy is defined as the time between leaf fall and bud burst and is represented by the progress of the curves for the mean time of bud beak (MTB), (Figure 1). MTB values increased starting from the middle of November and buds reached steady-state peak in December and January depending on cultivars. For "Bourjassate noire" and "Longue d'août" steady-sates were at high level in the middle of December. However, for others cultivars, it was at 2 or 3 weeks later, depending on the year. MTB were at high values in December for the first year but until January for the second year. This difference could be linked to chill units recorded in November which induced bud dormancy.

The average MTB varied with the cultivar and did not appear to be related to origin of the cultivar: "Filalia" (36.5) "Ournakssi” (56.5 d), "Ghouddane” (39.9 d), "Kadota” (56.9 d), "Lerida” (35.6 d), "Bourjassote noire” (77.3 d) and "Longue d'Août" (42.4 d). Relative intensity of dormancy depended on the cultivar and was deeper for "Borjassote noire", "Kadota” and "Ournakssi”. According to Duncan's classification, cultivars were classified into 3 groups: 1) "Bourjassote noire"; 2) "Kadota", “Ournaksi” and 3) "Longue Aout”-“Ghoddane”, "Filalia”, "Lerida”. Over all dates of sampling, "Bourjassate Noire”, "Kadota" and "Ournakssi" exhibited a high MTB values for the two years. The responses of cultivars across the two years were not similar. In fact, comparison of data showed significant differences between cultivars (Table 3). Environmental characteristics had an effect on dormancy and year had a significant effect (Table 3). MTB were higher during the first year of experiment than the second one for all cultivars (Figure 1). MTB stayed at high level during January when the cold was most intense. Average data of MTB plotted with chilling availability (Figure 2) shows similar pattern for the two years. The curves exhibit the relation between chill accumulation and the importance of MTB. The increase of dormancy started in the middle of November and decreased drastically in February.

Forcing buds during the cold period (December-January) did allow for only a low bud break percentage for all cultivars (Figure 2) and bud break didn't reach zero. This behaviour seems to be related to differences in physiological state of buds. The mean time of bud break decreased in the beginning of February. At this period, temperatures increased and responses of cultivars to heat seem to be similar (Figure 3). The acquisition of capacity of growth was relatively rapid and the rates obtained during the last week of February were situated between $90 \%$ and $100 \%$ (Figure 2). Buds seem to be submitted to one period of steady-state level which represents a period of winter dormancy. The removal of such dormancy exhibits accumulation of a chill quantity which was calculated for the first and second year to be about 450 and 400 hours, respectively.

\section{Discussion and Conclusion}

The present study provides information about dormancy characteristic of seven fig cultivars which have different geographic origins over two years under Moroccan conditions. The period from the full leaf fall to bud-break does not appear to reflect the origin of the cultivars. There is only a small variation in this characteristic in the cultivars (10 to 20 days) which could be linked to vegetative growth during the previous season.

Table 3. Table of variance analysis.

\begin{tabular}{cccc}
\hline Source & FD & Mean square & Pr $>$ F \\
\hline Variety (Var) & 6 & 6614.16 & 0.0016 \\
Year & 1 & 60650.55 & $<0.0001$ \\
Var*Year & 6 & 1624.75 & 0.4665 \\
Date & 7 & 15791.23 & $<0.0001$ \\
Year*Date & 7 & 11400.01 & $<0.0001$ \\
Var*Date & 42 & 1932.10 & 0.3881 \\
Var.*Year*Date & 42 & 1117.34 & 0.9433 \\
\hline
\end{tabular}



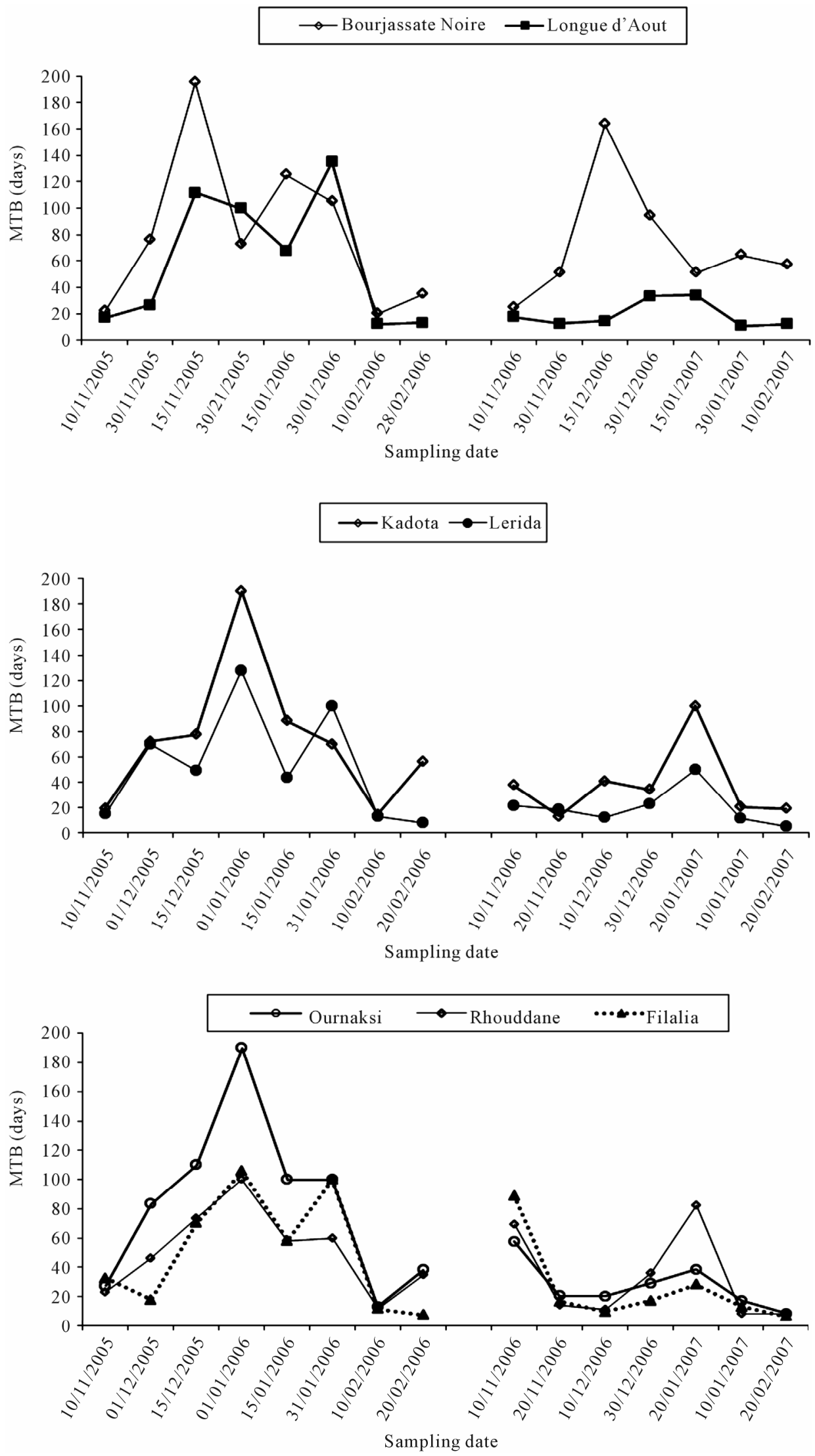

Figure 1. Mean time of bud break (MTB) for single node cutting of seven fig cultivars in Morocco. 

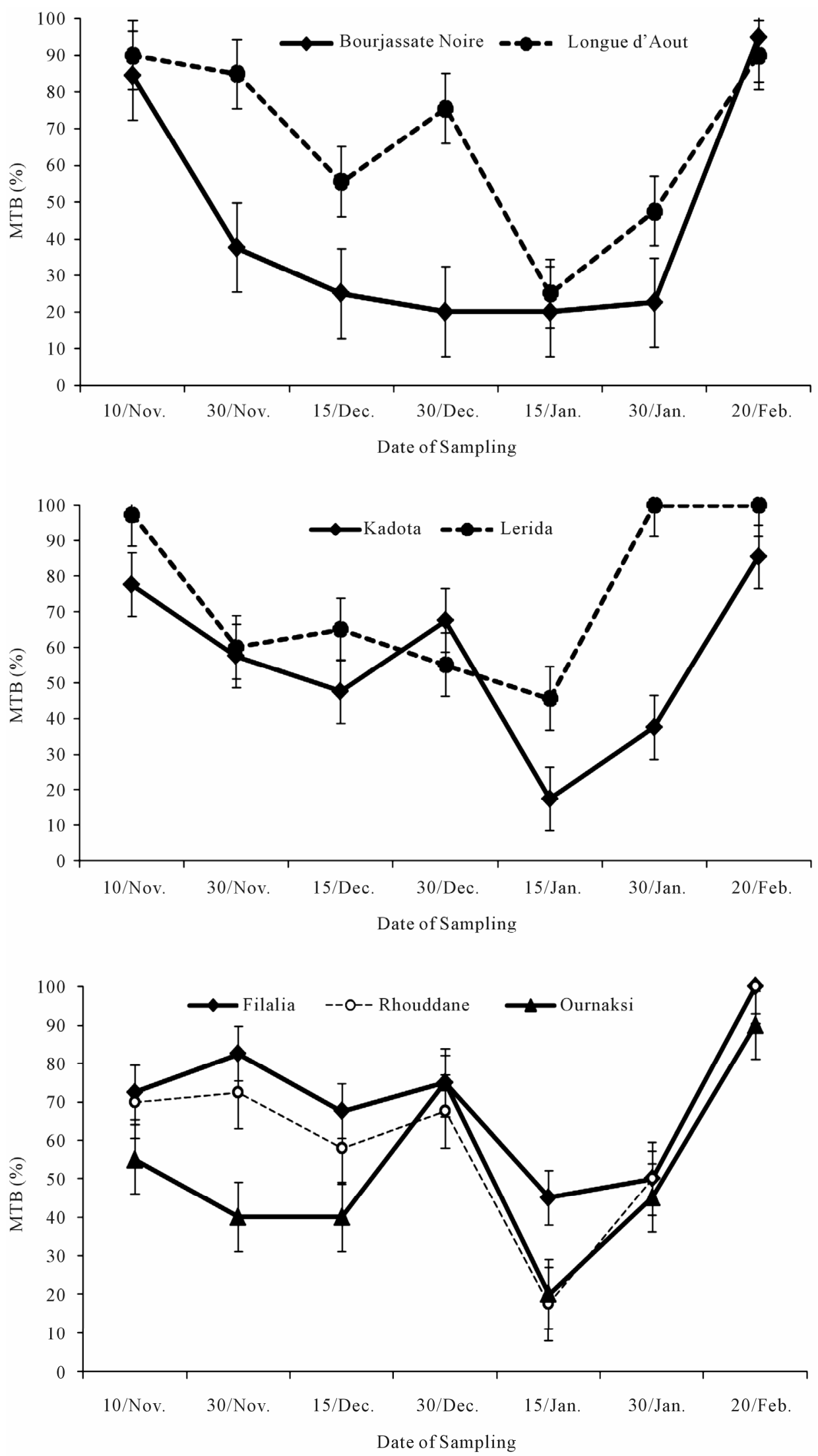

Figure 2. Monthly chilling availability and average of MTB for single node cutting of seven fig cultivars in Morocco. 

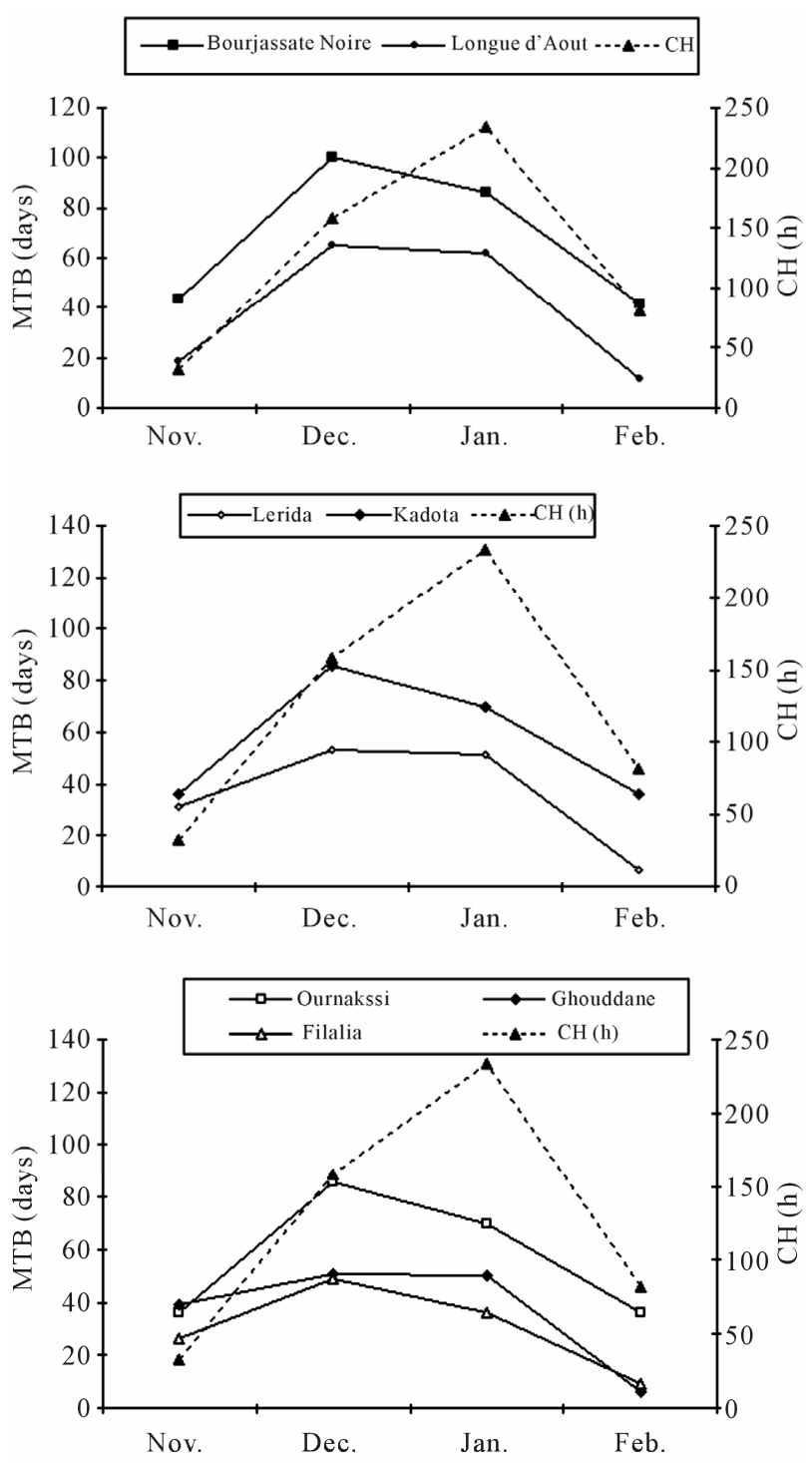

Figure 3. Cumulative bud burst relative to dates of sampling of seven fig cultivars in Morocco.

The evolution of bud-break showed the same pattern of results for two years. Curves were characterized by one steady-state peak of buds obtained during the winter when the chill units recorded were at high amount. MTB didn't exceed 200 days indicating that fig seems to have not deep dormancy in comparison with other species like cherry or apple in the same country. The acquisition of bud growth's capacity was rapid with a high rate of bud break at the end of winter. Fig didn't show symptoms of prolonged dormancy and duration of chilling was sufficient to overcome it especially when the winter chilling plays a major role in the overcome dormancy. This type of response to chilling is different to response reported for peach [28], apple [26] and sweet cherry [9]. In fig, buds seem to be submitted to one period of steady-state level which represents a period of winter dormancy in contrast to rosaceous species where MTB evolution exhibits two periods. The first one corresponds to correlative inhibition period which elapsed by a few weeks from the second one. Fig lost its growth capacities and correlative inhibitions established during the summer didn't appear in these circumstances. The period of dormancy was short in contrast to apple tree where 30 - 40 days were sufficient to complete rest. Elimination of dormancy was quick in contrast with apple which was progressive under similar climatic conditions [26]. The missing buds break wasn't observed on fig under these climatic conditions.

Data provides also an indication of chilling requirement of fig and indicates that chilling hours needed for bud break were lower for all cultivars. Period of dormancy was short and not so deep and all cultivars tested seem to have a low chill requirement. Therefore, dormancy is not a real issue for the cultivars tested and these specie is well adapted to Mediterranean (Morocco) conditions. It still particularly characterised by a high requirements of spring and summer temperatures for rapid growth. Hence, successful cultivation of fig trees is possible if a warm growing season is followed by a relatively cold winter to break dormancy.

\section{Acknowledgements}

Publication cost was supported by the MCA Project (USA).

The authors would like to acknowledge the assistance of Craig Ledbetter (USA) and Jamal Charafi in their helpful editing of the manuscript.

\section{REFERENCES}

[1] J. H. Weinberger, "Chilling Requirements of Peach Varieties," Proceeding, American Society of Horticultural Sciences, Vol. 56, 1950, pp. 122-128.

[2] R. Rageau, "Croissance et Débourrement des Bourgeons de Pêcher (Prunus persica L. Batsh)," Compte Rendu Académie des Sciences, Paris, Série D, Sciences Naturelles, Vol. 8, No. 226, 1978, pp. 1845-1848.

[3] P. Champagnat, "Rest and Activity in Vegetative Buds of Tree,” Annals de Science Foresterie, Vol. 46, 1989, pp. 9s-26s. doi:10.1051/forest:19890501

[4] J. Crabbé, "Dormancy," Encyclopedia of Agricultural Science, Vol. 1, 1994, pp. 597-611.

[5] R. Rageau and J. C. Mauget, "Dormancy Dynamics and Phenology in Peach, Apple and Walnut Trees under Prolonged Mild Winter Temperatures in Heated Greenhouse,” Acta Horticulturae, Vol. 199, 1974, p. 71.

[6] K. Mahmood, J. G. Carew, P. Hadley and N. H. Battey, "The Effect of Chilling and Post-Chilling Temperatures on Growth and Flowering of Sweet Cherry (Prunus avium L.)," Journal of Horticultural Science and Biotechnology, Vol. 75, No. 5, 2000, pp. 598-601. 
[7] A. Oukabli, A. Mamouni, M. Laghezali, M. Ater, K. Bouchaïb, J. P. Roger and F. Kjellberg, "Genetical Variablity in Morrocan Fig (Ficus carica L.) Based on Morphological and Pomological Data,” Acta Horticulturae, Vol. 605, 2003, pp. 311-318.

[8] J. M. Alonso, J. M. Ason, M. T. Espiau and R. Socias I Company, "Determination of Endodormancy Break in Almond Flower Buds by a Correlation Model Using the Average Temperature of Different Day Interval and Its Application to the Estimation of Chill and Heat Requirement and Blooming Date," Journal of the American Society for Horticultural Science, Vol. 130, No. 3, 2005, pp. 308-318.

[9] A. Oukabli and A. Mahhou, "Dormancy in Sweet Cherry (Prunus avium L.) under Mediterranean Climatic Conditions," Biotechnology Agronomic Society Environment, Vol. 11, 2007, pp. 133-139.

[10] R. Pouget, "Recherches Physiologiques sur le Repos Végétatif de la Vigne (Vitis vinifera L.): la Dormance des Bourgeons et le Mécanisme de sa Disparition,” Annale Amélioration des Plantes, Vol. 13, 1993, pp. 1-247.

[11] B. Bidabe, “Action de la Température sur l’Evolution des Bourgeons de Pommier et Comparaison de Méthodes de Contrôle de l'Epoque de Floraison," Annales De Physiologie Végétale, Vol. 9, No. 1, 1967, pp. 65-86.

[12] E. A. Richardson, S. D. Seeley and D. R. Walker, “A Model for Estimating the Completion of Rest for 'Redhaven' and 'Elberta' Peach Trees,” HortScience, Vol. 9, No. 4, 1974, pp. 331-332.

[13] D. E. Linvill, "Calculating Chilling Hours and Chill Units from Daily Maximum and Minimum Temperature Observations,” HortScience, Vol. 25, No. 1, 1990, pp. 14-16.

[14] I. J. Condit, “The Fig," The Chronica Botanica Company, Waltham, 1947, p. 220.

[15] L. Ferguson, T. J. Michalides and H. H. Shorey, "The California Fig Industry,” Horticultural Review, Vol. 12, 1990, pp. 409-490.

[16] F. Mendes-Pereira, “Cultura da Figuera,” Série Fruticultura Boletin, No. 2, Livroceres Ltda. Piracicaba, Brasil, 1981, p. 73.

[17] A. Flores, “La Higuera,” Mundi-Prensa, Madrid, 1990.

[18] P. Melgarejo, “La Higuera (Ficus carica L.),” Universidad Politécnica de Valencia, Orihuela, 1996, p. 83.

[19] E. Ôzeker and M. Isfandiyaroglu, "Evaluation of Table
Fig Cultivars in Cesme Peninsula,” Acta Horticulturae, Vol. 480, 1998, pp. 55-60.

[20] C. Botti, N. Franck, L. Prat, D. Ionnidis and B. Morales, "The Effect of Climatic Conditions on Fresh Fig Fruit Yield, Quality and Type of Crop,” Acta Horticulturae, Vol. 605, 2003, pp. 37-43.

[21] M. Pasqual, N. M. J. Chalfun, P. M. Norberto, L. F. Dutra, and J. M. Cavalcante-Alves, "Early Yielding of Unripe Figs cv. Roxo de Valinhos,” Acta Horticulturae, Vol. 605, 2003, pp. 125-130.

[22] Anonyme, "Bilan des Arbres Fruitiers," Direction de Développement des Filières de Production. Ministre de l’Agriculture et des Pêches Maritimes, 2010.

[23] B. Khadari, A. Oukabli, M. Ater, A. Mamouni, J. P. Roger and F. Kjellberg, "Molecular Characterization of Moroccan Fig Germplasm Using Intersimple Sequence Repeat and Simple Sequence Repeat Markers to Establish a Reference Collection,” HortScience, Vol. 40, 2004, pp. 29-32.

[24] R. Rageau, J. L. Julien and N. Ollat, “Approches du Contrôle de la Croissance des Bourgeons dans le Context de l'Arbre Entire (107-120)," In: P. Cruiziat and J. P. Lagouard, Eds., Actes de l'École Chercheurs Bioclimatologie, INRA, 3-4 Avril 1995, Le Croisic, France, Tome 1: De la Plante au Couvert Vegetal, Paris Editions, 1996, pp. 107-120.

[25] J. Nigond, "Recherches sur la Dormance des Bourgeons de la Vigne,” Annales de Physiologie Végétale, Vol. 9, 1967, pp. 102-107.

[26] A. Zguigal, A. Chabar, D. E. Walali-Loudiyi and J. Crabbe, "Caractéristiques de la Dormance des Bourgeons du Pommier dans les Régions à Hiver Doux," Biotechnologie, Agronomie, Société et Environnement, Vol. 10, 2006, pp. 131-137.

[27] A. Oukabli, S. Bartolini and R. Viti, “Anatomical and Morphological Study of Apple (Malus x Domestica Borth.) Flower Buds Growing under Inadequate Winter Chilling," Journal of Horticultural Science and Biotechnology, Vol. 78, No. 4, 2003, pp. 580-585.

[28] J. P. Overcash and J. A. Campbell, "The Effects of Intermittent Warm and Cold Periods on Breaking the Rest Period of Peach Leaf Buds,” Proceedings of the American Society for Horticultural Science, Vol. 66, 1955, pp. 87-92. 